\title{
Understanding E-Commerce Assurance Seals: An Analytical Framework
}

Te-Wei Wang, (E-mail: wangte@ fiu.edu), Florida International University Chih-Chen Lee, (E- mail: leecc@ fiu.edu), Florida International University

Ena Rose-Green, Southern Illinois University, Edwardsville

\begin{abstract}
Trust seals provide a business assurance service in e-commerce. Vendors employ trust seals to increase the perception of their trustworthiness. In this paper, we create an analytical framework that we use to group trust seals into five categories: (1) comprehensive certificate provider, (2) seller evaluation service, (3) market evaluator, (4) market assurance service, and (5) niche service. Our framework provides an easy means for online shoppers to differentiate trust seals and motivate seal providers to develop new services.
\end{abstract}

\section{Introduction}

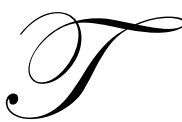

rust is a basic element in business activities. This is even more so in the context of electronic commerce where there is limited people-to-people contact [Brynjolfsson and Smith 2000]. Hoffman, Novak and Peralta [1999] found that consumers' lack of trust is a major deterrent to conducting business online. Consequently, in a bid to enhance online commerce, many organizations, private and public, have provided various kinds of "seals" or assurance services with the objective of increasing the consumers' level of trust. Popular examples of such seals are WebTrust provided by AICPA, BETTERWEB by PriceWaterHouseCoopers, and the Reliability program by Better Business Bureau. The various types of seals provide different assurances. For example, some seals provide assurance of security, while others provide assurance of privacy. Most companies conducting web-based business have adopted several seals.

Extant research shows that web-assurance services are useful. For example, both Mauldin and Arunachalam [2002] and Kimery and McCord [2002] find that assurance services can promote trust when the user's buying intention is high. Several studies have shown that consumers usually do not have enough information, such as merchant validity or product/pricing information, to make proper buying decisions [e.g. Grabner-Kraeuter 2002; Sirdeshmukh, Singh, and Sabol 2002]. Consumers use seals to reduce their information gathering efforts. The problem, however, is that consumers usually trust seals blindly. Both Houston and Taylor [1999] and Mauldin and Arunachalam's [2002] noticed that consumers do not differentiate seals. Incorrect interpretation of assurance services may lead to wrong expectations of merchants. Consequently, disputes may arise in transactions, leading to distrust. It is important for consumers to understand the kinds of assurance that seals provide.

The purpose of our paper is to provide an analytical framework for consumers to differentiate various web seals with minimal effort. To achieve this goal, we proceed as follows: (1) From literature review, we create a theoretical framework (a classification scheme) identifying the role of trust in both traditional markets and electronic commerce. (2) We identify a list of seals currently available in the United States. (3) We use our framework as an analytical tool to evaluate the seals identified in step 2. (4) Finally, we interpret our results and summarize our findings as a foundation for future research.

This paper can benefit both practitioners and academics. The grouping identified in this paper may help merchants to determine the proper seals to use on their web sites. It may also help consumers to discriminate among seals. For the seal providers, our classification framework identifies opportunities for both new seal development and seal policy improvement. This paper contributes to academics by identifying future research opportunities. 


\section{Framing the Trust Concept: The Theoretical Foundation}

Trust is a concept that has been studied in many disciplines and from different perspectives. The perception and definition of trust depend on the context and the discipline being studied. Lewicki and Bunker [1995] conducted a thorough literature search to define trust in both professional and intimate relationships. They noted that personality psychologists generally view trust as an individual trait, social psychologists view trust as a characteristic of interpersonal transactions, while economists and sociologists view trust as an institutional phenomenon. They, along with other researchers, such as Sitkin, Burt, and Camerer [1998], also stressed the importance of identifying the context in which trust is studied before any theory-building/verification exercise. Since most trust seals target the B2C market, we set our study in the context of B2C e-commerce.

Prior research (Marketing research, in particular) investigated and focused on the antecedents and consequences of trust in a buyer-seller relationship [e.g., Doney and Cannon 1997; Ruyter, Moorman and Lemmink 2001]. Researchers have treated the concept of trust as an institutional phenomenon [North, 1990]. In this line of research, the contextual factors surrounding a judgment of trust are emphasized. Examples of the antecedents of trust that had been studied include reputation, customers' satisfaction with previous outcomes, relationship length, salesperson's likeability, and sales person's expertise etc. [e. g., Andaleeb 1996; Andaleeb and Anwar 1996]. Examples of the consequences of trust include customers' satisfaction, customers' commitment, and customers' intention to cooperate etc. [e.g., Crosby, Evans and Cowles 1990; Doney and Cannon 1997].

In our paper, we adopt the view of social psychologists and treat the concept of trust as an institutional phenomenon. We investigate whether current available seals provide comprehensive certification in the e-commerce setting. The first step of our investigation is to define the concept of trust.

Trust has been defined, in a general sense, as a person's or an organization's "confidence in others," "positive expectation," or "willingness to be vulnerable [Mayer, Davis and Schoorman 1995]." To date, there is no universally accepted definition of trust among scholars. In fact, there may never be a consensus on the definition of trust. However, some commonality can still be found from different definitions. Sitkin, Burt, and Camerer [1998] note that regardless of the underlying discipline, risk is considered to be an essential component of trust. Sheppard and Sherman [1998] also support this notion. They note that trust is accepting the risks associated with the type and depth of a relationship. The emphasis on risk matches the calculative view of trust by many economists. For example, Williamson [1993] advocate that risk is an essential component used by people to determine trust.

Another commonality among different definitions of trust is the requirement of relationships (i.e., interdependence [Williamson and Craswell 1993; Lewichi and Bunker 1995; Jarvenpaa, Knoll and Leidner 1998]). Trust exists in relationships. It can exist in relationships among people [Granovetter 1985], between people and organizations [Zucker 1986], and among organizations [Zucker 1986]. To extend this concept even further, we can presume that trust can exist between people and things and also among things. For instance, contemporary network operation systems such as Microsoft Windows NT and Windows 2000 have long adopted "building trust relationship" as one important decision during the process of designing network infrastructure. Furthermore, since a relationship is a necessary condition for trust, both the roles of trustor and trustee can be identified [Sheppard and Sherman 1998]. That is, "trust" has directions. It is a psychological (for people) or mechanical state (for organizations or things) from a trusting party to a trusted party.

In summary, the following working definition of trust is used in this paper. Trust is a personal, organizational or mechanical status. It is people's willingness (for human systems) or a contract (for non-human system) to take risks in a relationship.

\section{A Process Framework to Identify the Sub-dimensions of Trust}

Recently, researchers have recognized that trust is a multi-dimensional construct [Sirdeshmukh, Singh and Sabol 2002; Sitkin, Burt and Camerer 1998; Sheppard and Sherman 1998]. A method frequently used to define the sub-dimensions of trust is to identify the different types of trust-relationship and different risks associated with each 
type of relationship. For example, Sheppard and Sherman [1998] studied the sub-dimensions of trust and developed a model to classify relationships in terms of form and depth. They note that there are four types of relationships: shallow dependency, shallow interdependency, deep dependency and deep interdependency. They also note that there are three types of risks associated with each relationship: (1) the risk of unreliability, (2) the risk of indiscretion, and (3) the risk of poor coordination.

Adopting the same approach, we develop our classification scheme by identifying the types of relationships, and the types of risks involved in e-commerce practices. However, recognizing that there may be many different ways to define the types of relationships and risks, we choose to classify relationships and risks by using the following process-oriented model.

Marketing literature has long defined product markets as potential buyers grouped by geographical regions, size or demographic distributions [Sissors 1966]. Recent marketing research also includes sellers as necessary entities in a market [Geroski 1998]. Following the development of the Internet and electronic markets, Market have become so complex that they fail to exist if supporting functions are missing. These supporting functions include financial services, technologies, government regulations and competitive environments etc. [Weinstein 1994; Malone, Yates and Benjamin 1994]. We term these supporting functions "market mechanism." Consistent with prior literature, we define market mechanism as "an abstract entity consisting of distributor, distribution technology, financial service provider, financial transaction technology, and other information technologies and their vendors [Malone, Yate and Benjamin 1994].”

Based on this market trichotomy (buyer, seller, and market mechanism), trusting relationships in ecommerce should include (minimally) relationships between buyer and seller, buyer and market mechanism, and seller and market mechanism. We graphically represent the six possible relationships among the three trading parties required to build electronic commerce in Figure 1.

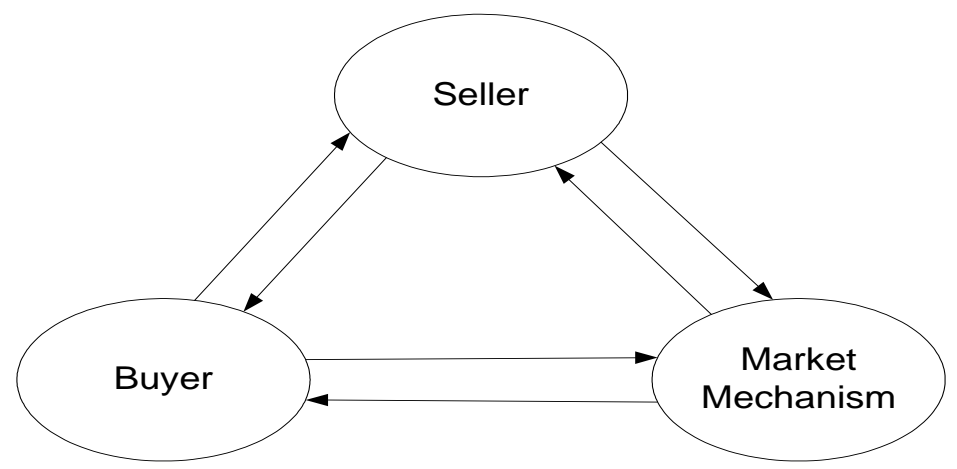

Figure 1. The Relationships of E-commerce

The consumer buying process in a B2C market can be very complex. Consistent with prior research, in our analysis, we divide the process into four phases: (1) evaluation phase, (2) purchasing phase, (3) order-fulfillment phase and (4) after-sale phase [e.q., Clarke 2001; Berry, Carbone, and Haeckel 2002]. We graphically represent these four phases in figure.

In the evaluation phase, sellers prepare product information and determine trading policies. They also determine what and how information should be disclosed. Buyers, on the other hand, have to decide on how much effort they will put into collecting product information, comparing prices and making purchase decisions. Finally, the market mechanism has to (1) provide certain mechanisms (or services) for sellers to present/promote their information and (2) provide channels or services for buyers to collect and organize product information. 


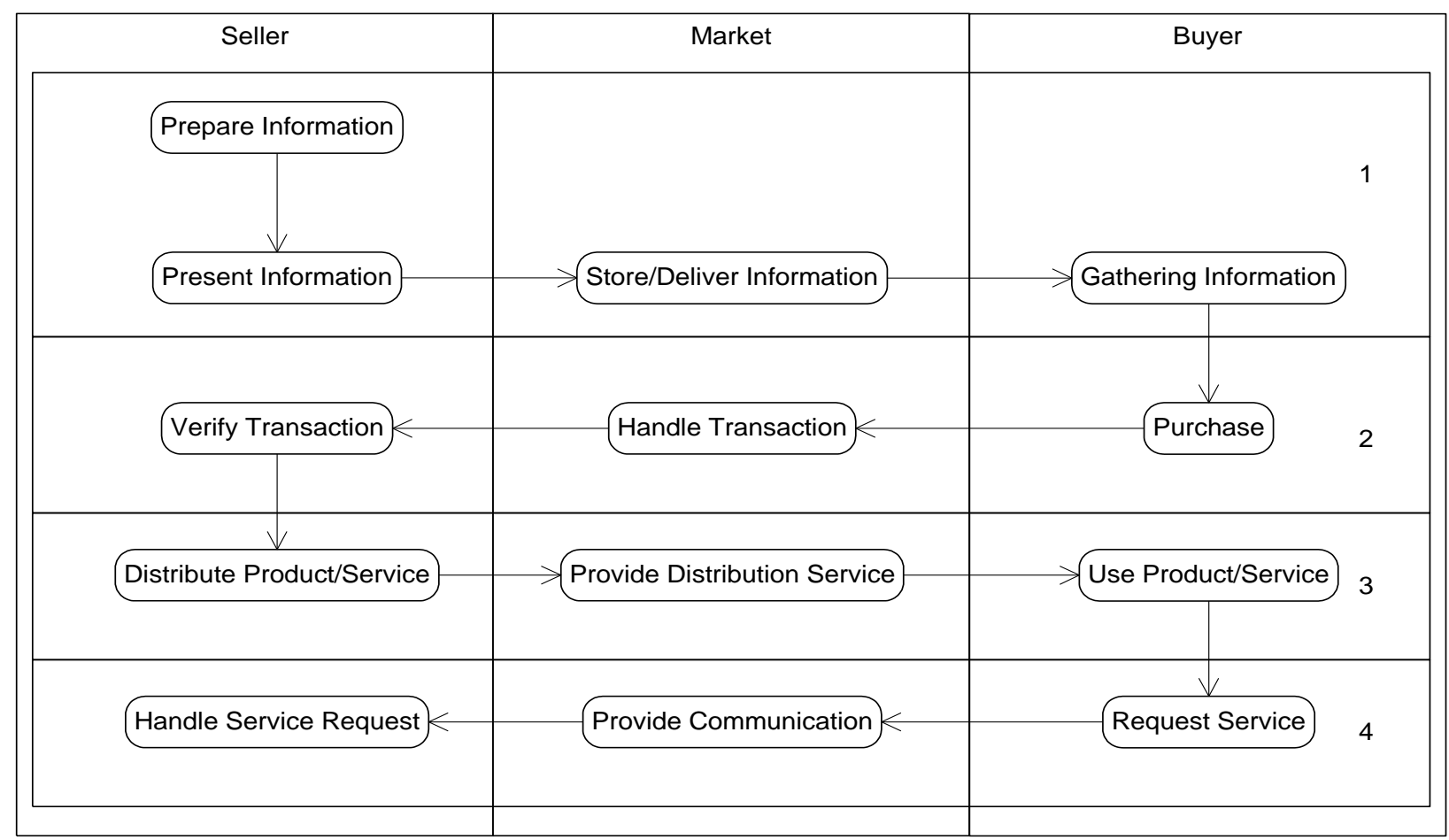

Figure 2. A Typical E-commerce Transaction Process

In the evaluation phase, each of the three parties incurs different types of risks. Sellers take the risk that the market mechanism cannot effectively deliver their product information to buyers. They also take the risk of buyers misinterpreting their product information. Buyers take the risk that sellers may not fully disclose product information and trading policies and the risk that the market mechanism may not be able to effectively disclose sellers' information on a timely basis. At the same time, the market mechanism bears the risk of both buyers and sellers' malicious intent to disrupt the normal market information presentation and communication functions.

In the purchasing phase, buyers make the decision to buy products from particular sellers. They then inform the sellers, sign contracts, and/or make payments. Sellers, in this phase, verify the contracts or payments and prepare to distribute products. The market mechanism provides both a communication channel between buyers and sellers and the service of handling payments. In this phase, sellers incur a market unreliability risk. Buyers take the risk of security breach from the transaction mechanism, the risk of sellers exposing their personal information, and the risk of failed transactions. The market, similar to previous phase, takes the risk of unreliable buyers and sellers' behaviors.

In the order fulfillment phase, sellers prepare products, select distribution methods, deliver products, and track the distribution process. Buyers monitor the distribution process, examine the product and confirm the completion of product distribution. The market mechanism may provide distribution alternatives and provide relevant tools (to process) and information for both buyers and sellers to monitor the distribution process. Therefore, buyers bear the risks of receiving poor quality products from the sellers and untimely/unreliable delivery from distribution channels. In this phase, sellers incur the risk of unreliable channel services, such as inaccurate tracking information, damaged products, or delayed deliveries. The market mechanism incurs the risk that both buyers and sellers may use the distribution tools and information inappropriately.

In the after-sale phase, buyers may request after-sale services, either directly from the seller or through a third-party agent. The market mechanism serves both as a potential mediator and a communication medium. If buyers have after-sale service requests, sellers may or may not take action to satisfy the buyers' requests. In this 
phase, sellers incur product liability risks. Buyers take the risk that sellers will not provide efficient and effective after-sale services.

We adopt the Sheppard and Sherman's [1998] definitions of risks involved in relationships and modify them for the e-commerce setting. We determine that there are essentially two types of risks involved in every trust relationship: the "risk of information disclosure" and the "risk of task reliability". The risk of information disclosure is the risk that the trustee will not disclose relevant information fully and accurately. For example, sellers may not fully disclose their privacy policies. The risk of task reliability is the risk that the trustee will not perform the agreedupon tasks. For example, sellers may not deliver quality products or they may not be discrete with the buyer's private information.

Based on the above discussion, we develop Table 1 identifying 16 sub-dimensions of trust. Instead of describing the six possible trust-relationships, we simplify the framework by describing the responsibilities of the three trustees, the buyer, the seller, and the market mechanism. Furthermore, since the objective of this paper is to help consumers differentiate among various seals, we exclude buyers as one of the interested trustees, resulting in two trustees, the seller and the market mechanism.

Table 1. The 16 Trust Sub-dimensions

\begin{tabular}{|c|c|c|}
\hline & Seller & Market Mechanism \\
\hline \multirow[t]{4}{*}{ Trustee's Information Disclosure Risks } & 1. Evaluation Phase & 9. Evaluation Phase \\
\hline & 2. Purchasing & 10. Purchasing \\
\hline & 3. Order-Fulfillment & 11. Order-Fulfillment \\
\hline & 4. After-Sale & 12. After-Sale \\
\hline \multirow[t]{4}{*}{ Trustee's Task Reliability Risks } & 5. Evaluation Phase & 13. Evaluation Phase \\
\hline & 6. Purchasing & 14. Purchasing \\
\hline & 7. Order-Fulfillment & 15. Order-Fulfillment \\
\hline & 8. After-Sale & 16. After-Sale \\
\hline
\end{tabular}

Column 1 of Table 1 presents the two types of risks involved in e-commerce relationships: the risk of information disclosure and the risk of task reliability. Column two and three present the buyers' information disclosure risk and task reliability risk for each phase of the market process from the seller and the market mechanism respectively.

\section{An Exploratory Analysis of Current Web Seals}

We used Table 1 to analyze some currently available assurance services (seals). The unit of analysis in this study is each individual seal. Some companies offer many different seals to cover different interest groups. We treated each seal as an independent unit. We used two methods to identify currently available seals. First, we utilized two popular search engines, google.com and the Microsoft search engine, to find seals. We used two key words: "trust" and "seal", in the queries. All seals identified with country postfix in their URL were excluded. Second, the search results were given to 200 students (both accounting and MIS majors) at a large sate university in the United States. The students were given the opportunity to earn bonus points by identifying additional seals. Table 2 lists all the seals identified through this process. These seals were used as our sample for analysis.

Next we used Table 1 as our coding instrument. The three listed authors were the coders. We chose to limit the number of coders involved in the process for validity reasons. For coding of latent content, too many coders involved in an early stage research project may result in wrong interpretations of the coding instrument [Babbie 1994, p. 311]. We also believe that independent coders are not required in an exploratory research. The coders obtained information about each seal by visiting its Web site. We coded each seal based on its functionalities or features as described in its publicly available documentations, which include FAQ, disclaimers, principles and 
Table 2. Sample Seals

\begin{tabular}{|c|c|c|}
\hline Sponsor & Seal Program & Web Site \\
\hline ABAecom & SiteCertain Seal & $\begin{array}{l}\text { http://www.abaecom.com/prd_prd_sc.h } \\
\text { tm }\end{array}$ \\
\hline AICPA & Web Trust & http://webtrust.org/ \\
\hline \multirow{3}{*}{$\begin{array}{l}\text { The Council of Better Business } \\
\text { Bureaus }\end{array}$} & BBB online reliability seal & http://www.bbbonline.com/ \\
\hline & BBB Online privacy seal & \\
\hline & BBB Online kid's privacy & \\
\hline Better Internet Bureau Association & Quality Assurance & http://www.better-internet-bureau.org/ \\
\hline BuzRate.com & BizRate.com seal & http://www.BizRate.com \\
\hline Digital Signature Trust (DST) & TrustID Certificate & http://www.digsigtrust.com/home.html \\
\hline ePublicEye.com & Web Watch Dog & http://www.epubliceye.com/index.htm \\
\hline $\begin{array}{l}\text { Entertainment Software rating Board } \\
\text { (ESRB) }\end{array}$ & ESRB Privacy online & http://www.esrb.org/ \\
\hline GeoTrust & True Site & http://www.geotrust.com/ \\
\hline Internet Content Rating Association & ICRA Label & http://www.icra.org/ \\
\hline Invisible Hand Software & PrivacyBot & http://privacybot.com/ \\
\hline PriceWaterHouseCoopers & The Better Web Program & http://www.pwcbetterweb.com/ \\
\hline Privacy Secure, Inc. & Privacy Secure Seal & http://privacysecure.com/index.html \\
\hline Quality Testing Lab & QTL Licensing Program & $\begin{array}{l}\text { http://www.keyword.com/cd/qualitytes } \\
\text { tinglabs/homepage.htm }\end{array}$ \\
\hline SafeSerf & SafeSurf Logo & http://www.safesurf.com/ \\
\hline Safe Shopping Network & Tested for Safety Program & http://thesafetysearch.com/index.cfm \\
\hline The Netcheck Commerce Bureau & Netcheck Membership seal & http://netcheck.com/ \\
\hline TRUSTe & Trustee Privacy & http://www.truste.com/ \\
\hline & E-Health Program & \\
\hline & Children's Seal Program & \\
\hline & EU Safe Harbor Program & \\
\hline Trustsecure & ICSA Security Certificate & http://www.truesecure.com/ \\
\hline VeriSign & SSL Certificate & http://www.verisign.com/ \\
\hline
\end{tabular}

guidelines, and/or application requirements etc. We used a simple "Yes" or "No" to describe if a certain seal provides assurance of a particular cell in table 1 . After each coder completed all his/her evaluations, we compared our notes and identified the differences. We also set certain "rules" to resolve differences in coding (see Table 3).

\section{Interpretation of Results}

A completed coding sheet is presented in the appendix. Based on the pattern shown in our results, we classified Internet seals into five basic types: Comprehensive Certificate Provider, Seller Evaluation Services, Market Evaluator, Market Assurance Service, and Niche Service (table 4a to 4e). The "Comprehensive Certificate Provider" includes AICPA's Web Trust seal and Price Waterhouse Cooper's BetterWeb seal. Both of these seals provide services similar to ISO9000 certificates that require trustees to document all their business practices and offer certificates after certain auditing procedures. The "Seller Evaluation Services" include: BBBOnline's Reliability Program, ePublicEye seal, Privacy Secure Seal, Quality Testing Labs' QT Mark, and Netcheck.com evaluation service. This category represents the largest group in our study and provides assurance services about the seller but not the market. The third category, "Market Evaluator," includes SafeShoppingNetwork and BizRate.com. This group differs from the "Seller Evaluation Services" in that they provide certain assurances about market mechanism. Seals in this group evaluate task reliability but not information disclosure. Unfortunately, the current two members of this group are themselves market builders, thus, rendering their assurances suspicious. 
Table 3: Coding Rules

\begin{tabular}{|c|c|c|}
\hline & Seller & Market \\
\hline \multirow[t]{4}{*}{$\begin{array}{l}\text { Trustee's } \\
\text { Information } \\
\text { Disclosure }\end{array}$} & $\begin{array}{l}\text { Does the seal require its members to follow certain } \\
\text { rules to describe its product/service information? } \\
\text { Does the seal verify its members' identities? }\end{array}$ & $\begin{array}{l}\text { Does the seal require its members to use certain site } \\
\text { certification-authority (CA) service? } \\
\text { Does the seal require its members' service provider s } \\
\text { to disclose their service-level agreement? } \\
\text { Does the seal require the site to provide tools for } \\
\text { information search and price comparison? }\end{array}$ \\
\hline & $\begin{array}{l}\text { Does the seal require its members to have certain } \\
\text { security processes to securely handle customer's } \\
\text { information? } \\
\text { Does the seal require its members to disclose their } \\
\text { sales terms completely? }\end{array}$ & $\begin{array}{l}\text { Does the seal require its members to adopt certain } \\
\text { technologies to ensure security? }\end{array}$ \\
\hline & $\begin{array}{l}\text { Does the seal require its members to describe their } \\
\text { order-fulfillment process and standard? }\end{array}$ & $\begin{array}{l}\text { Does the seal require its members to describe their } \\
\text { order-fulfillment partners? }\end{array}$ \\
\hline & $\begin{array}{l}\text { Does the seal require its members to follow certain } \\
\text { privacy standards and disclose their privacy policies? } \\
\text { Does the seal require its members to describe their } \\
\text { conflict resolution policies? }\end{array}$ & $\begin{array}{l}\text { Does the seal require its members to provide } \\
\text { alternative customer dispute handling services? } \\
\text { Does the seal require its members to provide } \\
\text { sufficient channels for after-sale services? }\end{array}$ \\
\hline \multirow[t]{4}{*}{$\begin{array}{l}\text { Trustee's } \\
\text { Task } \\
\text { Reliability }\end{array}$} & $\begin{array}{l}\text { Does the seal ensure that its members present } \\
\text { product/service information effectively and } \\
\text { accurately? }\end{array}$ & $\begin{array}{l}\text { Does the seal evaluate the performance of the CA } \\
\text { service? } \\
\text { Does the seal evaluate web sites and network's (ISP) } \\
\text { performance? } \\
\text { Does the seal ensure market mechanism's information } \\
\text { services? }\end{array}$ \\
\hline & $\begin{array}{l}\text { Does the seal verify the sellers' transaction control } \\
\text { processes? }\end{array}$ & $\begin{array}{l}\text { Does the seal verify whether a chosen security } \\
\text { technology is adequate and up-to-date? }\end{array}$ \\
\hline & $\begin{array}{l}\text { Does the seal verity that the seller delivers the } \\
\text { good/service completely, accurately and promptly? }\end{array}$ & $\begin{array}{l}\text { Does the seal verify that the seller's logistic partner } \\
\text { delivers the goods/services completely, accurately and } \\
\text { promptly? }\end{array}$ \\
\hline & $\begin{array}{l}\text { Does the seal ensure that its members protect } \\
\text { customer's privacy as promised? } \\
\text { Does the seal evaluate its member's customer } \\
\text { services? }\end{array}$ & $\begin{array}{l}\text { Does the seal ensure other after-sale service } \\
\text { provider's performances? }\end{array}$ \\
\hline
\end{tabular}

Table 4a Comprehensive Certification Provider

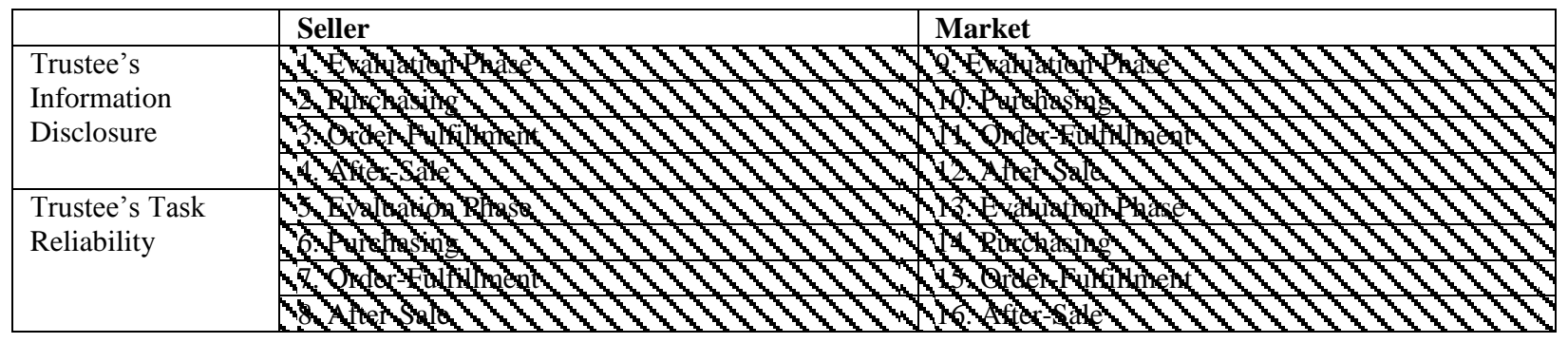


Table 4b Seller Evaluation Service

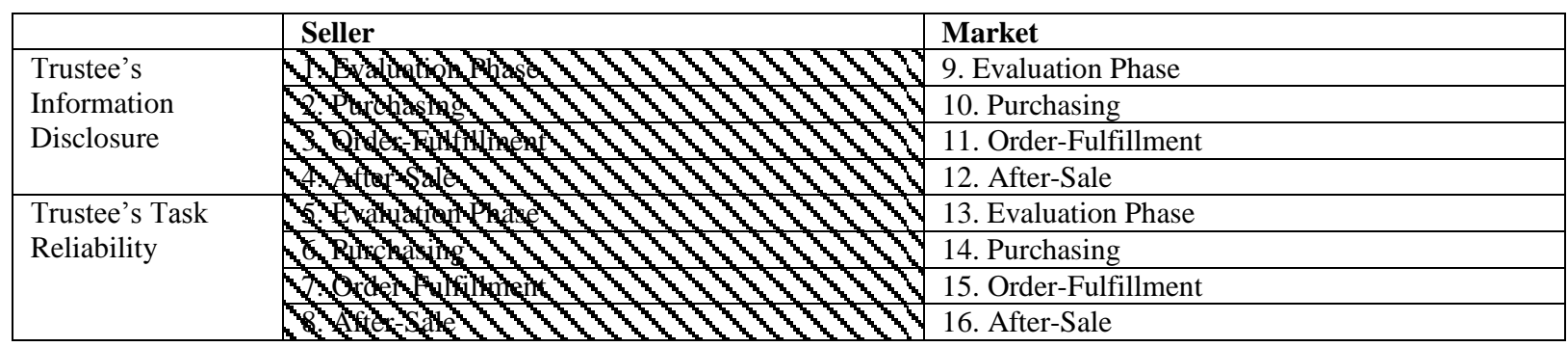

Table 4c Market Evaluators

\begin{tabular}{|l|l|l|}
\hline & Seller & Market \\
\hline \multirow{3}{*}{$\begin{array}{l}\text { Trustee's } \\
\text { Information }\end{array}$} & 1. Evaluation Phase & 9. Evaluation Phase \\
\cline { 2 - 3 } & 2. Purchasing & 10 . Purchasing \\
\cline { 2 - 3 } & 3. Order-Fulfillment & 1 . Order-Fulfillment \\
\cline { 2 - 3 } $\begin{array}{l}\text { Trustee's Task } \\
\text { Reliability }\end{array}$ & 4. After-Sale & 12 . After-Sale \\
& &
\end{tabular}

Table 4d Market Assurance Service

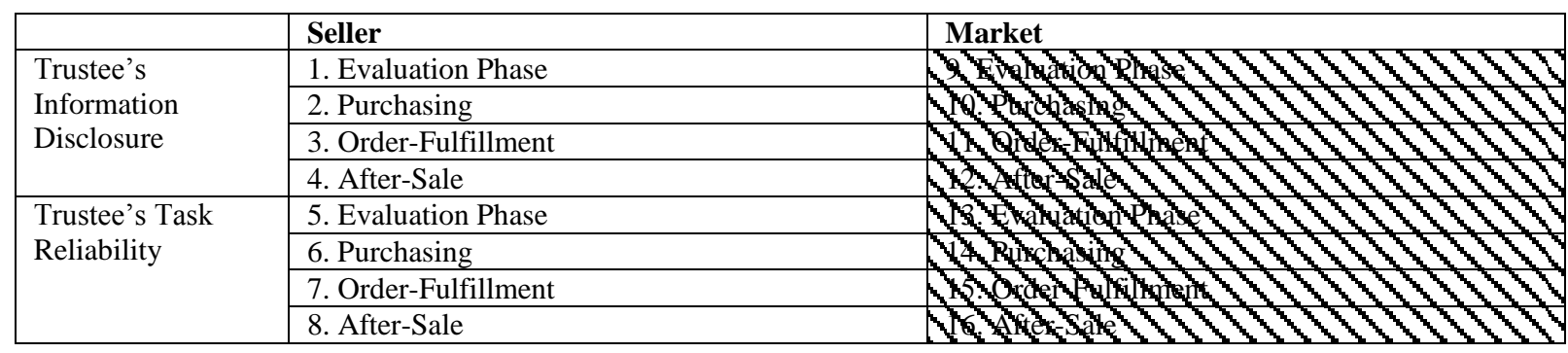

Table 4e Niche Service

\begin{tabular}{|c|c|c|}
\hline & Seller & Market \\
\hline \multirow{4}{*}{$\begin{array}{l}\text { Trustee's } \\
\text { Information } \\
\text { Disclosure }\end{array}$} & 1. Evaluation Phase & 9. Evaluation Phase \\
\hline & 2 pruebdsing $/ \angle Z$ & 10. Purchasing \\
\hline & 3. Order-Fulfillment & 11. Order-Fulfillment \\
\hline & 4. After-Sale & 12. After-Sale \\
\hline \multirow{4}{*}{$\begin{array}{l}\text { Trustee's Task } \\
\text { Reliability }\end{array}$} & 5. Evaluation Phase & 13. Evaluation Phase \\
\hline & 6. Purchasing & (4. Richasitis, 1$)$ \\
\hline & 7. Order-Fulfillment & 15. Order-Fulfillment \\
\hline & 8. After-Sale & 16. After-Sale \\
\hline
\end{tabular}

The "Market Assurance Service" group consists of Trust ID and SSL Certificate. Companies providing these two seals sell either certification authority or Internet security software and services. Strictly speaking, they cannot be classified as Trust Seal since they do not act as third party evaluators. However, they do allow their customers to display their logos (this practice is very similar to the "Intel Inside" logo on many personal computers). This provides name recognition assurances to consumers by displaying the logo. 
The final category, the "Niche Service" group, includes various privacy seals provided by TRUSTe, ESRB Privacy Seal, TruSecure Seal and ABAecom's SiteCertain Seal. Each seal in this group covers only one or two dimensions in our framework. Some of these seals provide even more narrow services targeting a particular industry or a particular interest group.

\section{Conclusion}

This research is exploratory in nature. The main purpose of this paper is to layout a foundation for future investigation on trust seals by creating a framework against which currently available seals may be evaluated.

In this paper, we introduced the process perspective into trust research. We coded each seal based on its functionalities or features as described in their publicly available documentation. Our goal was not to judge the effectiveness (in terms of evaluating method and outcomes) of each seal

We identified currently available seals and used our framework to classify the seals into five categories. The categories were determined by the assurances they provide. The five categories are (1) comprehensive certificate provider, (2) seller evaluation service, (3) market evaluator, (4) Market assurance service, and (5) niche service.

We excluded authenticity services from our coding because it covers topics beyond the scope of our framework. The only mechanism currently available to ensure customer's validity and prevent customers' wrong doings in e-commerce is the digital key certificate technology. This service treats customers as an additional trustee that requires evaluation. It verifies the trustworthiness of customers. Currently, only Digital Signature Trust explicitly provides this service. However, this may be a fruitful area for seal providers to broaden their services in the future.

For future research we will answer the following questions. Can our framework raise the awareness and increase customers' capability in differentiating trust seals? During the coding processes, we also identified the following questions as potential research topics. What factors make one seal more popular than another? What are the consequences of using different evaluation or auditing methods to issue seals? What is the association between the seal development process and government or other 3rd party regulation efforts? Compared to other selfregulation efforts, such as movie rating system, what are the commonalities and differences?

We think that these seals play a vital role in promoting the use of e-commerce. Therefore, continuing this line of research is important to both the research community and to e-commerce practitioners. Currently this line of research is limited. However, the growing e-commerce market makes this line of research extremely valuable. We think that our efforts here will trigger new research and motivate new developments in e-commerce.

\section{References}

1. Andaleeb, S.S.(1996) "An Experimental Investigation of Satisfaction and Commitment in Marketing Cannels: The Role of Trust and Dependence", Journal of Retailing, (96)1, pp. 77-93.

2. Andaleeb, S. S. and S. F. Anwar (1996) "Factors Influencing Customer Trust in Salespersons in a Developing Country", Journal of International Marketing, (4)4, pp. 35-52.

3. Anderson, J. C. and J. A. Narus (1990) "A Model of Distributor Firm and Manufacturer Firm Working Partnerships", Journal of Marketing, (54)1, pp. 42-58.

4. Babbie, E. (1994) The Practice of Social Research, Seventh Edition, Wadsworth Publishing Company, Belmont, California.

5. Berry, L. L., L. P. Carbone, and S. H. Haeckel (2002) "Managing the Total Customer Experience", Sloan Management Review, (43)3, pp. 85.

6. Brynjolfsson, E. and M. D. Smith (2000) "Frictionless Commerce? A Comparison of Internet and Conventional Retailers", Management Sciences, (46)4, pp. 563-585.

7. Clarke, G. (2001) "Confirming Satisfaction as an Attitude within the Service-Buying Process", Journal of Consumer Behavior, (1)2, pp. 111-124. 
8. Crosby, L. A., K. R. Evans, and D. Cowles (1990) "Relationship Quality in Services Selling: An Interpersonal Influence Perspective", Journal of Marketing, (54)3, pp. 68-81.

9. Dasgupta, P. (1988) "Trust as Commodity" in D. Gambetta (ed.) Trust: Making and Breaking Cooperative Relations, Basil Backwell Inc., New York.

10. Doney, P. M. and J. P. Cannon (1997) "An Examination of the Nature of Trust in Buyer-Seller Relationship", Journal of Marketing, (61)2, pp. 35-51.

11. Ganesan, S. (1994) "Determinants of Long-Term Orientation in Buyer-Seller Relationships", Journal of Marketing, (58)2, pp. 1-19.

12. Geroski, P. A. (1998) "Thinking Creatively about Markets", International Journal of Industrial Organization, (16)6, pp. 677-696.

13. Glover, S. M., S. W. Liddle, and D. F. Prawitt (2001) ebusiness: Principles and strategies for accountants. Prentice Hall, New Jersey.

14. Grabner-Kraeuter, S. (2002) “The Role of Consumers' Trust in Online-Shopping”, Journal of Business Ethics, (39)1/2, pp. 43-50.

15. Granovetter, M. S. (1985) "Economic Action and Social Structure", American Journal of Sociology, (91), pp. 481-510.

16. Hoffman, D. L., T. P. Novak, and M. Peralta (1999) "Building Consumer Trust Online", Communication of the ACM, (42)4, pp. 80-85.

17. House, R., D. M. Rousseau, and M. Tomas-Hunt (1995) "The Meso Paradigm: A Framework for the Integration of Micro and Macro Organizational Behavior" in L. L. Cummings \& B. M. Staw (eds.) Research in Organizational Behavior, (17), pp. 71-114, Greenwich, CT JAI Press.

18. Houston, R. W. and G. K. Taylor (1999) "Consumer Perceptions of CPA WebTrust Assurances : Evidence of an Expectation Gap", International Journal of Audition, (3)1, pp. 89-105.

19. Jarvenpaa, S. L., K. Knoll and D. E. Leidner (1998) "Is Anybody Out There? Antecedents of Trust in Global Virtual Teams", Journal of Management Information Systems, (14)4, pp. 29-64.

20. Kimery, K. M. and M. McCord (2002). "Third-Party Assurances: Mapping the Road to Trust in eRetailing”, Journal of Information Technology Theory and Application, (4)2, pp. 63-82.

21. Lewicki, R. J., and B. B. Bunker (1995) "Trust in Relationships: A Model of Development and Decline" in B. Bunker and J. Rubin (ed.) Conflict, Cooperation and Justice, San Francisco, Jossey-Bass, pp. 133-173.

22. Malone, T. W.; J. Yates, and R. I. Benjamin (1994) "Electronic Markets and Electronic Hierarchies" in T. J. Allen and M. S. Scott Morton (ed.) Information and the Corporation of the 1990s, Oxford University Press, New York, Oxford, pp. 61-81.

23. Mauldin, E. and V. Arunachalam (2002) "An Experimental Examination of Alternative Forms of Web Assurance for Business-to-Consumer e-commerce", Journal of Information Systems, (16) supplement, pp. 33-54.

24. Mayer, R. C., J. H. Davis, and D. Schoorman (1995) “An Integrative Model of Organizational Trust", Academy of Management Review, (20)3, pp. 709-734.

25. North, D. C. (1990). Institutions, Institutional Change, and Economic Performance, New York, Cambridge University Press.

26. Ruyter, K., L. Moorman, and J. Lemmink (2001) "Antecedents of Commitment and Trust in CustomerSupplier Relationships in High Technology Markets”, Industrial Marketing Management, (30)3, pp. 271286.

27. Sirdeshmukh, D., J. Singh, and B. Sabol (2002) "Consumer Trust, Value and Loyalty in Relational Exchanges", Journal of Marketing, (66)1, pp. 15-37.

28. Sitkin, S. B., R. S. Burt, and C. Camerer (1998) "Not so Difference after all: A Cross-Discipline View of Trust", Academy of Management, (23)3, pp. 393-404.

29. Sissors, J. Z. (1966) “What is Market?”, Journal of Marketing, (30)3, pp. 17-21.

30. Sheppard, B. H. and D. M. Sherman (1998) "The Grammars of Trust: A Model and General Implications", The Academy of Management Review, (23)3, pp. 422-437.

31. Stewart, K. J. (2003) "Trust Transfer on the World Wide Web", Organization Science, (14)1, pp.5-17

32. Weber, R. (1997). Ontological Foundations of Information Systems, Coopers and Lybrand, Australia.

33. Weinstein, A. (1994). "Market Definition in Technology-Based Industry: A Comparative Study of Small Versus Non-Small Companies", Journal of Small Business Management, (32)4, pp. 28-37. 
34. Williamson, O. E., and R. Craswell (1993) "Calculativeness, Trust, and Economic Organization”, Journal of Law and Economics, (36)1, pp.453.

35. Zucker, L. G. (1986) "Production of Trust: Institutional Sources of Economic Structure 1840-1920" in B. M. Starw and L. L. Cummings (ed.) Research in Organizational Behavior, (8), Greenwich, CT: JAI Press, pp. 53-111.

\section{Appendix}

\section{ABAecom: SiteCertain}

\begin{tabular}{|c|c|c|c|c|}
\hline \multicolumn{5}{|l|}{ ABACom: sitecertain } \\
\hline & Seller & & Market & \\
\hline \multirow{4}{*}{$\begin{array}{l}\text { Trustee's Information } \\
\text { Disclosure }\end{array}$} & 1. Evaluation Phase & $\mathrm{N}$ & 1. Evaluation Phase & $\mathrm{Y}$ \\
\hline & 2. Purchasing & $\mathrm{N}$ & 2. Purchasing & $\mathrm{N}$ \\
\hline & 3. Order-Fulfillment & $\mathrm{N}$ & 3. Order-Fulfillment & $\mathrm{N}$ \\
\hline & 4. After-Sale & $\mathrm{N}$ & 4. After-Sale & $\mathrm{N}$ \\
\hline \multirow{4}{*}{$\begin{array}{l}\text { Trustee’s Task } \\
\text { Reliability }\end{array}$} & 1. Evaluation Phase & $\mathrm{N}$ & 1. Evaluation Phase & $\mathrm{N}$ \\
\hline & 2. Purchasing & $\mathrm{N}$ & 2. Purchasing & $\mathrm{N}$ \\
\hline & 3. Order-Fulfillment & $\mathrm{N}$ & 3. Order-Fulfillment & $\mathrm{N}$ \\
\hline & 4. After-Sale & $\mathrm{N}$ & 4. After-Sale & $\mathrm{N}$ \\
\hline
\end{tabular}

AICPA: WetTrust
\begin{tabular}{|l|l|l|l|c|}
\hline & Seller & & Market & \\
\hline \multirow{4}{*}{$\begin{array}{l}\text { Trustee's Information } \\
\text { Disclosure }\end{array}$} & 1. Evaluation Phase & Y & 1. Evaluation Phase & Y \\
\cline { 2 - 5 } & 2. Purchasing & Y & 2. Purchasing & Y \\
\cline { 2 - 5 } & 3. Order-Fulfillment & Y & 3. Order-Fulfillment & Y \\
\cline { 2 - 5 } & 4. After-Sale & Y & 4. After-Sale & Y \\
\hline \multirow{3}{*}{ Trustee's Task } & 1. Evaluation Phase & Y & 1. Evaluation Phase & Y \\
\cline { 2 - 5 } & 2. Purchasing & Y & 2. Purchasing & Y \\
\cline { 2 - 5 } & 3. Order-Fulfillment & Y & 3. Order-Fulfillment & Y \\
\cline { 2 - 5 } & 4. After-Sale & Y & 4. After-Sale & \\
\hline
\end{tabular}

\section{BBBOnline: Reliability Program}

\begin{tabular}{|l|l|l|l|c|}
\hline & Seller & & Market & \\
\hline \multirow{4}{*}{ Trustee's Information } & 1. Evaluation Phase & Y & 1. Evaluation Phase & $\mathrm{N}$ \\
\cline { 2 - 5 } & 2. Purchasing & Y & 2. Purchasing & $\mathrm{N}$ \\
\cline { 2 - 5 } & 3. Order-Fulfillment & $\mathrm{N}$ & 3. Order-Fulfillment & $\mathrm{N}$ \\
\cline { 2 - 5 } & 4. After-Sale & $\mathrm{N}$ & 4. After-Sale & $\mathrm{N}$ \\
\hline \multirow{3}{*}{ Trustee's Task } & 1. Evaluation Phase & $\mathrm{Y}$ & 1. Evaluation Phase & $\mathrm{N}$ \\
\cline { 2 - 5 } & 2. Purchasing & $\mathrm{N}$ & 2. Purchasing & $\mathrm{N}$ \\
\cline { 2 - 5 } & 3. Order-Fulfillment & $\mathrm{N}$ & 3. Order-Fulfillment & $\mathrm{N}$ \\
\cline { 2 - 5 } & 4. After-Sale & $\mathrm{Y}$ & 4. After-Sale & $\mathrm{N}$ \\
\hline
\end{tabular}

\section{BizRate.com}

\begin{tabular}{|l|l|l|l|c|}
\hline & Seller & & Market & \\
\hline \multirow{4}{*}{$\begin{array}{l}\text { Trustee's Information } \\
\text { Processing }\end{array}$} & 1. Evaluation Phase & $\mathrm{N}$ & 1. Evaluation Phase & $\mathrm{N}$ \\
\cline { 2 - 5 } & 2. Purchasing & $\mathrm{N}$ & 2. Purchasing & $\mathrm{N}$ \\
\cline { 2 - 5 } & 3. Order-Fulfillment & $\mathrm{N}$ & 3. Order-Fulfillment & $\mathrm{N}$ \\
\cline { 2 - 5 } & 4. After-Sale & $\mathrm{N}$ & 4. After-Sale & $\mathrm{N}$ \\
\hline \multirow{3}{*}{$\begin{array}{l}\text { Trustee's Task } \\
\text { Reliability }\end{array}$} & 1. Evaluation Phase & $\mathrm{Y}$ & 1. Evaluation Phase & $\mathrm{Y}$ \\
\cline { 2 - 5 } & 2. Purchasing & $\mathrm{Y}$ & 2. Purchasing & $\mathrm{Y}$ \\
\cline { 2 - 5 } & 3. Order-Fulfillment & $\mathrm{Y}$ & 3. Order-Fulfillment & $\mathrm{Y}$ \\
\cline { 2 - 5 } & 4. After-Sale & $\mathrm{Y}$ & 4. After-Sale & $\mathrm{Y}$ \\
\hline
\end{tabular}


Digital Signature Trust: TrustID

\begin{tabular}{|l|l|l|l|c|}
\hline & Seller & & Market & \\
\hline \multirow{4}{*}{$\begin{array}{l}\text { Trustee's Information } \\
\text { Processing }\end{array}$} & 1. Evaluation Phase & $\mathrm{N}$ & 1. Evaluation Phase & $\mathrm{Y}$ \\
\cline { 2 - 5 } & 2. Purchasing & $\mathrm{N}$ & 2. Purchasing & $\mathrm{Y}$ \\
\cline { 2 - 5 } & 3. Order-Fulfillment & $\mathrm{N}$ & 3 . Order-Fulfillment & $\mathrm{N}$ \\
\cline { 2 - 5 } & 4. After-Sale & $\mathrm{N}$ & 4. After-Sale & $\mathrm{N}$ \\
\hline \multirow{3}{*}{$\begin{array}{l}\text { Trustee's Task } \\
\text { Reliability }\end{array}$} & 1. Evaluation Phase & $\mathrm{N}$ & 1. Evaluation Phase & $\mathrm{Y}$ \\
\cline { 2 - 5 } & 2. Purchasing & $\mathrm{N}$ & 2. Purchasing & $\mathrm{Y}$ \\
\cline { 2 - 5 } & 3. Order-Fulfillment & $\mathrm{N}$ & 3. Order-Fulfillment & $\mathrm{N}$ \\
\cline { 2 - 5 } & 4. After-Sale & $\mathrm{N}$ & 4. After-Sale & $\mathrm{N}$ \\
\hline
\end{tabular}

ePublicEye

\begin{tabular}{|l|l|l|l|c|}
\hline & Seller & & Market & \\
\hline \multirow{4}{*}{$\begin{array}{l}\text { Trustee's Information } \\
\text { Processing }\end{array}$} & 1. Evaluation Phase & $\mathrm{N}$ & 1. Evaluation Phase & $\mathrm{N}$ \\
\cline { 2 - 5 } & 2. Purchasing & $\mathrm{N}$ & 2. Purchasing & $\mathrm{N}$ \\
\cline { 2 - 5 } & 3. Order-Fulfillment & $\mathrm{N}$ & 3. Order-Fulfillment & $\mathrm{N}$ \\
\cline { 2 - 5 } & 4. After-Sale & $\mathrm{N}$ & 4. After-Sale & $\mathrm{N}$ \\
\hline \multirow{3}{*}{$\begin{array}{l}\text { Trustee's Task } \\
\text { Reliability }\end{array}$} & 1. Evaluation Phase & $\mathrm{Y}$ & 1. Evaluation Phase & $\mathrm{N}$ \\
\cline { 2 - 5 } & 2. Purchasing & $\mathrm{Y}$ & 2. Purchasing & $\mathrm{N}$ \\
\cline { 2 - 5 } & 3. Order-Fulfillment & $\mathrm{Y}$ & 3. Order-Fulfillment & $\mathrm{N}$ \\
\cline { 2 - 5 } & 4. After-Sale & $\mathrm{Y}$ & 4. After-Sale & $\mathrm{N}$ \\
\hline
\end{tabular}

\section{ESRB Privacy Seal}

\begin{tabular}{|l|l|l|l|c|}
\hline & Seller & & Market & \\
\hline \multirow{3}{*}{$\begin{array}{l}\text { Trustee's Information } \\
\text { Processing }\end{array}$} & 1. Evaluation Phase & $\mathrm{Y}$ & 1. Evaluation Phase & $\mathrm{N}$ \\
\cline { 2 - 5 } & 2. Purchasing & $\mathrm{Y}$ & 2. Purchasing & $\mathrm{N}$ \\
\cline { 2 - 5 } & 3. Order-Fulfillment & $\mathrm{N}$ & 3 . Order-Fulfillment & $\mathrm{N}$ \\
\cline { 2 - 5 } & 4. After-Sale & $\mathrm{N}$ & 4 . After-Sale & $\mathrm{N}$ \\
\hline \multirow{3}{*}{$\begin{array}{l}\text { Trustee's Task } \\
\text { Reliability }\end{array}$} & 1. Evaluation Phase & $\mathrm{Y}$ & 1. Evaluation Phase & $\mathrm{N}$ \\
\cline { 2 - 5 } & 2. Purchasing & $\mathrm{Y}$ & 2. Purchasing & $\mathrm{N}$ \\
\cline { 2 - 5 } & 3. Order-Fulfillment & $\mathrm{N}$ & 3. Order-Fulfillment & $\mathrm{N}$ \\
\cline { 2 - 5 } & 4. After-Sale & $\mathrm{N}$ & 4. After-Sale & $\mathrm{N}$ \\
\hline
\end{tabular}

Privacy Secure Inc.: Privacy Secure Seal

\begin{tabular}{|l|l|l|l|c|}
\hline & Seller & & Market & \\
\hline \multirow{4}{*}{$\begin{array}{l}\text { Trustee's Information } \\
\text { Processing }\end{array}$} & 1. Evaluation Phase & $\mathrm{Y}$ & 1. Evaluation Phase & $\mathrm{N}$ \\
\cline { 2 - 5 } & 2. Purchasing & $\mathrm{Y}$ & 2. Purchasing & $\mathrm{Y}$ \\
\cline { 2 - 5 } & 3. Order-Fulfillment & $\mathrm{N}$ & 3 . Order-Fulfillment & $\mathrm{N}$ \\
\cline { 2 - 5 } & 4. After-Sale & $\mathrm{Y}$ & 4. After-Sale & $\mathrm{N}$ \\
\hline \multirow{3}{*}{$\begin{array}{l}\text { Trustee's Task } \\
\text { Reliability }\end{array}$} & 1. Evaluation Phase & $\mathrm{Y}$ & 1. Evaluation Phase & $\mathrm{N}$ \\
\cline { 2 - 5 } & 2. Purchasing & $\mathrm{Y}$ & 2. Purchasing & $\mathrm{N}$ \\
\cline { 2 - 5 } & 3. Order-Fulfillment & $\mathrm{Y}$ & 3. Order-Fulfillment & $\mathrm{N}$ \\
\cline { 2 - 5 } & 4. After-Sale & $\mathrm{Y}$ & 4. After-Sale & $\mathrm{N}$ \\
\hline
\end{tabular}

\section{PriceWaterHouseCoopers: BetterWeb Seal}

\begin{tabular}{|l|l|l|l|c|}
\hline & Seller & & Market & \\
\hline \multirow{4}{*}{ Trustee's Information } & 1. Evaluation Phase & $\mathrm{Y}$ & 1. Evaluation Phase & $\mathrm{Y}$ \\
\cline { 2 - 5 } & 2. Purchasing & $\mathrm{Y}$ & 2. Purchasing & $\mathrm{N}$ \\
\cline { 2 - 5 } & 3. Order-Fulfillment & $\mathrm{Y}$ & 3. Order-Fulfillment & $\mathrm{N}$ \\
\cline { 2 - 5 } & 4. After-Sale & $\mathrm{Y}$ & 4. After-Sale & $\mathrm{Y}$ \\
\hline \multirow{4}{*}{$\begin{array}{l}\text { Trustee's Task } \\
\text { Reliability }\end{array}$} & 1. Evaluation Phase & $\mathrm{Y}$ & 1. Evaluation Phase & $\mathrm{Y}$ \\
\cline { 2 - 5 } & 2. Purchasing & $\mathrm{Y}$ & 2. Purchasing & $\mathrm{N}$ \\
\cline { 2 - 5 } & 3. Order-Fulfillment & $\mathrm{Y}$ & 3. Order-Fulfillment & $\mathrm{N}$ \\
\cline { 2 - 5 } & 4. After-Sale & $\mathrm{Y}$ & 4. After-Sale & $\mathrm{Y}$ \\
\hline
\end{tabular}


QualityTestinglabs: QTMark

\begin{tabular}{|l|l|l|l|c|}
\hline \multirow{3}{*}{$\begin{array}{l}\text { Trustee's Information } \\
\text { Processing }\end{array}$} & Seller & & Market & \\
\cline { 2 - 5 } & 1. Evaluation Phase & $\mathrm{Y}$ & 1. Evaluation Phase & $\mathrm{N}$ \\
\cline { 2 - 5 } & 2. Purchasing & $\mathrm{Y}$ & 2. Purchasing & $\mathrm{Y}$ \\
\cline { 2 - 5 } & 3. Order-Fulfillment & $\mathrm{Y}$ & 3. Order-Fulfillment & $\mathrm{N}$ \\
\cline { 2 - 5 } & 4. After-Sale & $\mathrm{Y}$ & 4. After-Sale & $\mathrm{N}$ \\
\hline \multirow{3}{*}{$\begin{array}{l}\text { Trustee's Task } \\
\text { Reliability }\end{array}$} & 1. Evaluation Phase & $\mathrm{Y}$ & 1. Evaluation Phase & $\mathrm{Y}$ \\
\cline { 2 - 5 } & 2. Purchasing & $\mathrm{Y}$ & 2. Purchasing & $\mathrm{N}$ \\
\cline { 2 - 5 } & 3. Order-Fulfillment & $\mathrm{Y}$ & 3. Order-Fulfillment & $\mathrm{N}$ \\
\cline { 2 - 5 } & 4. After-Sale & $\mathrm{Y}$ & 4. After-Sale & $\mathrm{N}$ \\
\hline
\end{tabular}

SafeSurf

\begin{tabular}{|l|l|l|l|c|}
\hline & Seller & & Market & \\
\hline \multirow{4}{*}{$\begin{array}{l}\text { Trustee's Information } \\
\text { Processing }\end{array}$} & 1. Evaluation Phase & $\mathrm{Y}$ & 1. Evaluation Phase & $\mathrm{N}$ \\
\cline { 2 - 5 } & 2. Purchasing & $\mathrm{N}$ & 2. Purchasing & $\mathrm{N}$ \\
\cline { 2 - 5 } & 3. Order-Fulfillment & $\mathrm{N}$ & 3. Order-Fulfillment & $\mathrm{N}$ \\
\cline { 2 - 5 } & 4. After-Sale & $\mathrm{Y}$ & 4. After-Sale & $\mathrm{N}$ \\
\hline \multirow{3}{*}{$\begin{array}{l}\text { Trustee's Task } \\
\text { Reliability }\end{array}$} & 1. Evaluation Phase & $\mathrm{N}$ & 1. Evaluation Phase & $\mathrm{Y}$ \\
\cline { 2 - 5 } & 2. Purchasing & $\mathrm{N}$ & 2. Purchasing & $\mathrm{N}$ \\
\cline { 2 - 5 } & 3. Order-Fulfillment & $\mathrm{N}$ & 3. Order-Fulfillment & $\mathrm{N}$ \\
\cline { 2 - 5 } & 4. After-Sale & $\mathrm{N}$ & 4. After-Sale & $\mathrm{N}$ \\
\hline
\end{tabular}

\section{SafeShoppingNetwork}

\begin{tabular}{|c|c|c|c|c|}
\hline & Seller & & Market & \\
\hline \multirow{4}{*}{$\begin{array}{l}\text { Trustee's Information } \\
\text { Processing }\end{array}$} & 1. Evaluation Phase & $\mathrm{N}$ & 1. Evaluation Phase & $\mathrm{N}$ \\
\hline & 2. Purchasing & $\mathrm{N}$ & 2. Purchasing & $\mathrm{N}$ \\
\hline & 3. Order-Fulfillment & $\mathrm{N}$ & 3. Order-Fulfillment & $\mathrm{N}$ \\
\hline & 4. After-Sale & $\mathrm{N}$ & 4. After-Sale & $\mathrm{N}$ \\
\hline \multirow{4}{*}{$\begin{array}{l}\text { Trustee's Task } \\
\text { Reliability }\end{array}$} & 1. Evaluation Phase & $\mathrm{Y}$ & 1. Evaluation Phase & $\mathrm{Y}$ \\
\hline & 2. Purchasing & $\mathrm{Y}$ & 2. Purchasing & $\mathrm{Y}$ \\
\hline & 3. Order-Fulfillment & $\mathrm{Y}$ & 3. Order-Fulfillment & $\mathrm{Y}$ \\
\hline & 4. After-Sale & $\mathrm{Y}$ & 4. After-Sale & $\mathrm{Y}$ \\
\hline
\end{tabular}

\section{Netcheck.com}

Netcheck.com
\begin{tabular}{|l|l|l|l|c|}
\hline \multirow{4}{*}{$\begin{array}{l}\text { Trustee's Information } \\
\text { Processing }\end{array}$} & Seller & & Market & \\
\cline { 2 - 5 } & 1. Evaluation Phase & Y & 1. Evaluation Phase & $\mathrm{N}$ \\
\cline { 2 - 5 } & 2. Purchasing & $\mathrm{Y}$ & 2. Purchasing & $\mathrm{N}$ \\
\cline { 2 - 5 } & 3. Order-Fulfillment & $\mathrm{N}$ & 3. Order-Fulfillment & $\mathrm{N}$ \\
\cline { 2 - 5 } & 4. After-Sale & $\mathrm{N}$ & 4. After-Sale & $\mathrm{N}$ \\
\hline \multirow{3}{*}{$\begin{array}{l}\text { Trustee's Task } \\
\text { Reliability }\end{array}$} & 1. Evaluation Phase & $\mathrm{Y}$ & 1. Evaluation Phase & $\mathrm{N}$ \\
\cline { 2 - 5 } & 2. Purchasing & $\mathrm{N}$ & 2. Purchasing & $\mathrm{N}$ \\
\cline { 2 - 5 } & 3. Order-Fulfillment & $\mathrm{N}$ & 3. Order-Fulfillment & $\mathrm{N}$ \\
\cline { 2 - 5 } & 4. After-Sale & $\mathrm{Y}$ & 4. After-Sale & $\mathrm{N}$ \\
\hline
\end{tabular}

TRUSTe Privacy Various

\begin{tabular}{|l|l|l|l|c|}
\hline & Seller & & Market & \\
\hline \multirow{4}{*}{$\begin{array}{l}\text { Trustee's Information } \\
\text { Processing }\end{array}$} & 1. Evaluation Phase & $\mathrm{N}$ & 1. Evaluation Phase & $\mathrm{N}$ \\
\cline { 2 - 5 } & 2. Purchasing & $\mathrm{N}$ & 2. Purchasing & $\mathrm{N}$ \\
\cline { 2 - 5 } & 3. Order-Fulfillment & $\mathrm{N}$ & 3. Order-Fulfillment & $\mathrm{N}$ \\
\cline { 2 - 5 } & 4. After-Sale & $\mathrm{Y}$ & 4. After-Sale & $\mathrm{N}$ \\
\hline \multirow{3}{*}{$\begin{array}{l}\text { Trustee's Task } \\
\text { Reliability }\end{array}$} & 1. Evaluation Phase & $\mathrm{N}$ & 1. Evaluation Phase & $\mathrm{N}$ \\
\cline { 2 - 5 } & 2. Purchasing & $\mathrm{N}$ & 2. Purchasing & $\mathrm{N}$ \\
\cline { 2 - 5 } & 3. Order-Fulfillment & $\mathrm{N}$ & 3. Order-Fulfillment & $\mathrm{N}$ \\
\cline { 2 - 5 } & 4. After-Sale & $\mathrm{Y}$ & 4. After-Sale & $\mathrm{N}$ \\
\hline
\end{tabular}


TruSecure

\begin{tabular}{|l|l|l|l|c|}
\hline & Seller & & Market & \\
\hline \multirow{3}{*}{$\begin{array}{l}\text { Trustee's Information } \\
\text { Processing }\end{array}$} & 1. Evaluation Phase & $\mathrm{N}$ & 1. Evaluation Phase & $\mathrm{N}$ \\
\cline { 2 - 5 } & 2. Purchasing & $\mathrm{Y}$ & 2. Purchasing & $\mathrm{N}$ \\
\cline { 2 - 5 } & 3. Order-Fulfillment & $\mathrm{N}$ & 3. Order-Fulfillment & $\mathrm{N}$ \\
\cline { 2 - 5 } & 4. After-Sale & $\mathrm{N}$ & 4. After-Sale & $\mathrm{N}$ \\
\hline \multirow{3}{*}{$\begin{array}{l}\text { Trustee's Task } \\
\text { Reliability }\end{array}$} & 1. Evaluation Phase & $\mathrm{N}$ & 1. Evaluation Phase & $\mathrm{N}$ \\
\cline { 2 - 5 } & 2. Purchasing & $\mathrm{Y}$ & 2. Purchasing & $\mathrm{N}$ \\
\cline { 2 - 5 } & 3. Order-Fulfillment & $\mathrm{N}$ & 3. Order-Fulfillment & $\mathrm{N}$ \\
\cline { 2 - 5 } & 4. After-Sale & $\mathrm{N}$ & 4. After-Sale & $\mathrm{N}$ \\
\hline
\end{tabular}

\section{VeriSign}

\begin{tabular}{|c|c|c|c|c|}
\hline & Seller & & Market & \\
\hline \multirow{4}{*}{$\begin{array}{l}\text { Trustee's Information } \\
\text { Processing }\end{array}$} & 1. Evaluation Phase & $\mathrm{N}$ & 1. Evaluation Phase & $\mathrm{N}$ \\
\hline & 2. Purchasing & $\mathrm{Y}$ & 2. Purchasing & $\mathrm{Y}$ \\
\hline & 3. Order-Fulfillment & $\mathrm{N}$ & 3. Order-Fulfillment & $\mathrm{N}$ \\
\hline & 4. After-Sale & $\mathrm{N}$ & 4. After-Sale & $\mathrm{N}$ \\
\hline \multirow{4}{*}{$\begin{array}{l}\text { Trustee's Task } \\
\text { Reliability }\end{array}$} & 1. Evaluation Phase & $\mathrm{N}$ & 1. Evaluation Phase & $\mathrm{N}$ \\
\hline & 2. Purchasing & $\mathrm{N}$ & 2. Purchasing & $\mathrm{Y}$ \\
\hline & 3. Order-Fulfillment & $\mathrm{N}$ & 3. Order-Fulfillment & $\mathrm{N}$ \\
\hline & 4. After-Sale & $\mathrm{N}$ & 4. After-Sale & $\mathrm{N}$ \\
\hline
\end{tabular}

